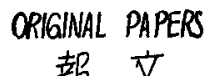

報 久

(40)
粒粉体材料の減率乾燥期間の過程解析*

桐栄良三(1) 林信也(2) - 内藤孝弘(3) 岡崎守男(1) ·安形正彦(5)
I. 緒言

粒粉体材料の熱風による定常乾燥条件下に括ける乾燥 特性を求めた。これによると減率乾燥速度は含水率に比 例して減少し，また材料内温度勾配は無視できる。これ に基づいて減率期間淿特ける任意の含水率に対応する材 料温度の变化を追跡した。

ついで熱風と村料が並流または向流に移動する不定常 乾燥条件のもとにおける，この種の材料の減率期間に括 ける材料温度变化を熱風条件および含水率の变数として 求める関係を導いた。この関係は連続式熱風乾燥器の設 計に用いることができる。
3 に示した。

d）気流乾燥によって粒子と熱風を並流に送りながら 乾燥した場合，粒子が終速に達した後は伝熱係数は一定 となるが，気流乾燥装置”によって硫化鉱”を乾燥した 場合（重量中位径 $0.33 \mathrm{~mm}$, 真比重 5.0 ), 実験より畭 蜗管長における含水率およびガス温度変化を求めて畭燥 速度が計算される。ただしこのままの值では管長てした がって翰燥条件の变化する不定常乾燥となるので，標準 条件を適当に定めて，実験から求めた值を標準条件での 乾燥速度に換算する。すなわち（実験からの腩燥速度） ×(標準条件での佰率乾燥速度/その点における乾燥条件

\section{II. 定常乾燥条件下の乾燥}

\section{1. 粒粉体材料の娍率速度曲楾}

粒粉体材料を種々の方法により乾燤する 場合にその特性曲楾を求めると以下のよう になる。

a）小球（硫酸ハリュウムの粉末を直径 $8 \mathrm{~mm}$ の球に成型したもの）を熱風中に烈 吊して乾燥を行った場合の乾燥速度の 1 例 を Fig. 1 に示した。この実験は粘土球を 石英螺旋科（石英線太さ $0.3 \mathrm{~mm}$ ，螺旋直 径 $20 \mathrm{~mm}$, 巻数 50）に揫吊し, 粘土球に 恒温，佰湿，恒風速の熱風を送り，屬㳬の 收縮長さをカセトメーターで測定して重量 の減少を求めた。精度は $1 \mathrm{mg} / 0.05 \mathrm{~mm}$ である。また同一試料を同じ位置におき，表面近く（表 面から内部へ $2 \mathrm{~mm}$ くらい) の位置に銅 $(30 \mu), \quad コ ン$ スタンタン $(60 \mu)$ の熱電対を挿入して温度変化を同時 に測定した。

b）满型摚拌乾燥器2)により硫安結晶 ${ }^{3)}$ (重量中位径 $0.3 \mathrm{~mm}$ )を层導加熱により擋拌しながら乾燥した場合 の特性曲楾の 1 例了を Fig. 2 に示した。

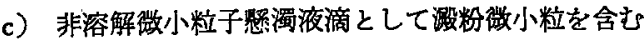
水滴（初期液滴径 $1.5 \sim 2 \mathrm{~mm}$, 浱度 $41 \%$ ) 熱風流れ

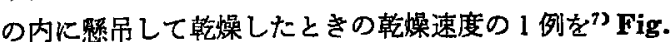

* 昭和 34 年 4 月 6 日受理
(1) 京大工
(2) 出光興産
（3）帝国人絽
(4) झ带レイ $ョ ン$
(5) 小野田セたン

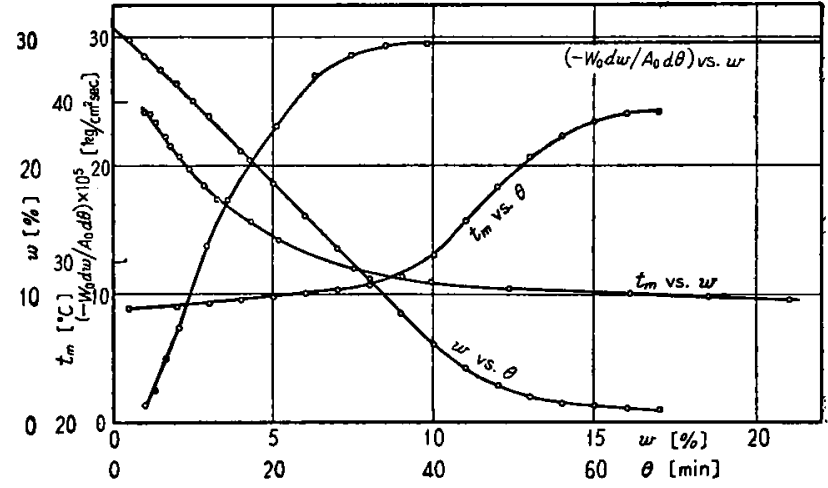

Fig. 1 Drying curve : small sphere (Run. 50) dia. $0.807 \mathrm{~mm}$, material BaSO, powder (100 pass) $t=40^{\circ} \mathrm{C}, H=0.0148, \bar{u}=1.0 \mathrm{~m} / \mathrm{sec}$

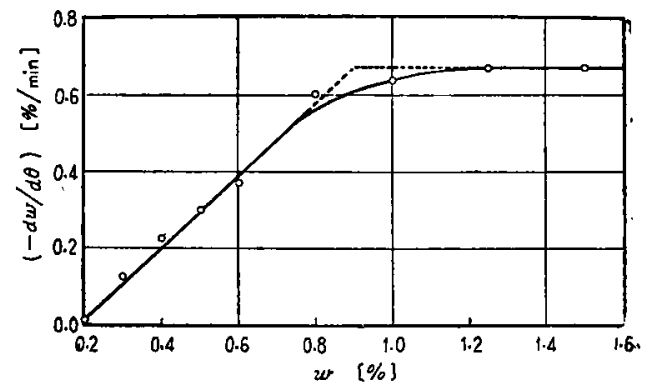

Fig. 2 Drying rate curve for $\left(\mathrm{NH}_{4}\right)_{2} \mathrm{SO}_{1}$ in a trough agitator dryer ${ }^{2)}$

30 r. p. m. ; $3 \mathrm{~kg}$-charge ; jacket steam press. $1.5 \mathrm{~kg} / \mathrm{cm}^{2}$.. gage ; $\left(\mathrm{NH}_{1}\right)_{2} \mathrm{SO}, \mathrm{wt}$. basis median dia. $0.3 \mathrm{~mm}$; initial $w=0.060$ 


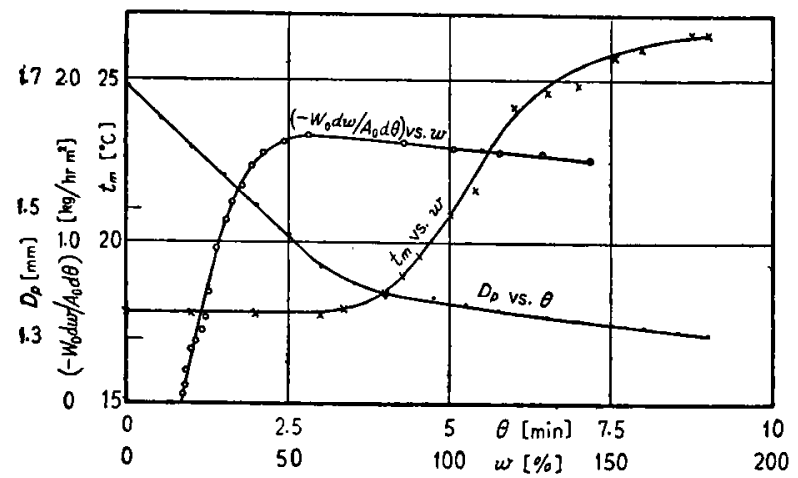

Fig. 3 Drying curve for the droplet containing starch") $t=26.6^{\circ} \mathrm{C}, H=0.0083, \bar{\alpha}=0.99 \mathrm{~m} / \mathrm{sec}$, initial conc. $41 \%$. initial dia. $1.685 \mathrm{~mm}$

下対する桓率雗燥速度）から求められる。終速圈での減 事䔡燥速度を計算して，これを標準条件下の定常乾燥の 值に計算しなおした数值の1例を Fig. 4 に示した。

Fig. 1 4 の减率速度曲線に着目すると 8 0.3 mm の粒粉体材料はその畭燥方式が種々变化してもその隇察 乾燥速度はほぼ含水率に比例して直線的に減少するもの とい光る。したがって熱風による乾燥の場合その速度は

$$
\begin{aligned}
W_{0}(-d w) / A_{0} d \theta & =k\left(H_{w}-H\right) F / F_{0} \\
& =h\left(t-t_{w}\right) F / r_{w} F_{c}=K F
\end{aligned}
$$

が成立すると考えてよい*。

\section{2. 粒粉体材料内部の温度勾㽞}

粒粉体材料と周囲空気間の熱量の授受は

$$
\begin{aligned}
& h A_{0}\left(t-t_{m s}\right) d \theta \\
& \quad=W_{0}(-d w) r_{m}+d\left[\int t_{m m}\left(c+c_{w} w\right) d W_{0}\right]
\end{aligned}
$$

となり，すし材料内に温度勾配がなければ

$$
h A_{0}\left(t-t_{m}\right) d \theta=W_{0}(-d w) r_{m}+W_{0}\left(c+c_{w} w\right) d t_{m}
$$

となるはずである。

Fig. 1 におげた径 $8 \mathrm{~mm}$ の球の実験において，減率 期間開始の時間（辆燥開始より $34 \mathrm{~min}$ ) とそのときの材 料温度をそれそれ起点にとり䋛横軸に材料温度と減率乾 嬠開始後の時間をとってその変化を点綴すると Fig. 5 の実線のようになる。一方乾燥速度 $\left(-W_{0} d w / A_{0} d \theta\right)$ は 実験值（Fig. 1) 加求められるので，各含水率したが って各時間についてのこの值を式（3）に代入すると，式 (3) は $t_{m}$ と $\theta$ の関係を表わす式となる。これょり $\theta$ K 対する $t_{m}$ の变化を試行法で求めて，同しくく減率乾蜗開 蛞時を起点として Fig. 5 K点緅すると破線のようにな る。実線と破線とは良好な一致を示している。すなわち この昜合では材料内部の温度勾配は考えなくてもよく，

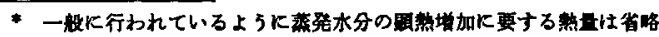
した。以下る同粖の近似で計算を進めた。

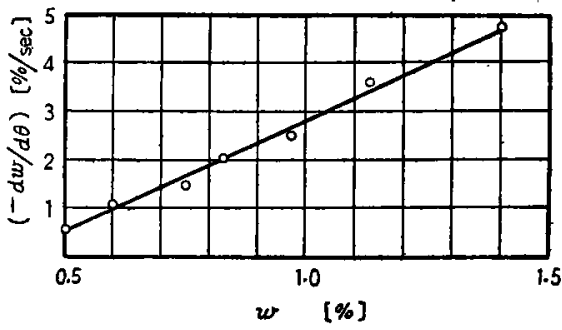

Fig. 4 Corrected decreasing drying rate curve for pyrite by pneumatic conveying drying ${ }^{45}$ at the terminal velocity zone

The drying rate obtained from the experiment is corrected to meet the value at that standard stational drying conditions, where $t=135, H=$ 0.0257 at $w=00083$. Pyrite : $w t$. basis median dia. $0.33 \mathrm{~mm}, \rho_{m}=5000 \mathrm{~kg} / \mathrm{m}^{3}$, initial $w=0.072$ at $w=0.014(t=140.7, H=0.0244, L=2.0)$ at $w=0.005$ $(t=125.7, H=0.0268, L=11.0$ )

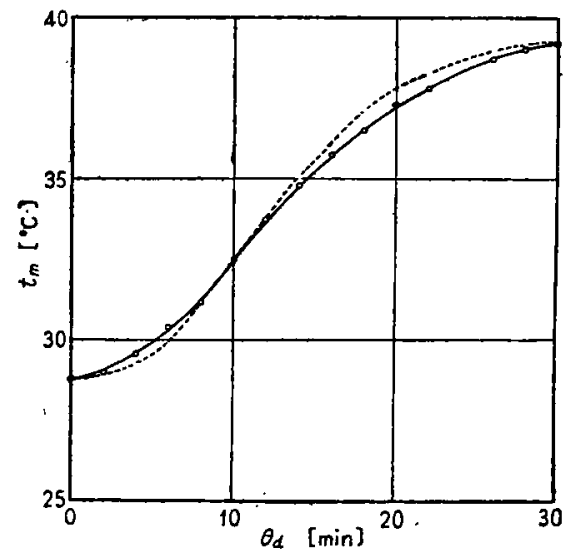

Fig. 5 Relation between material temperature and drying time at the decreasing drying rate period

This is the same experiment as shown in Fig. 1 - experimenal value ...... calculated value

式（3）が成立することが判る。 G. F. Bloomfield" 直径 $2 \mathrm{~cm}$ の泥灰土（marl）を整形した球を乾球温度 $60^{\circ} \mathrm{C}$, 湿球温度 $36^{\circ} \mathrm{C}$ の熱風中㴽吊して，表面と中心 の温度差を測定したところ，最高 $3^{\circ} \mathrm{C}$ の差があったが $1 \mathrm{~cm}$ 以下のものではきわめて僅小であろうと述へてい る。

粘土球の径を $3.86 \mathrm{~cm}$ とし $1 \mathrm{a}$ ）と同様な条件の下で 重量减少 (精度 $10 \mathrm{mg}$ 物理天科飞愁吊) を湘定し，同時 に球の各部分（表面各部分および中心）について温度の 湘定を行った結果を含水率対温度の関保として Fig. 6 と示した。熱風のあたる前面がもっとも高くついで侧面 そなり，背面が一番低くなるがこれらを平均した材料 


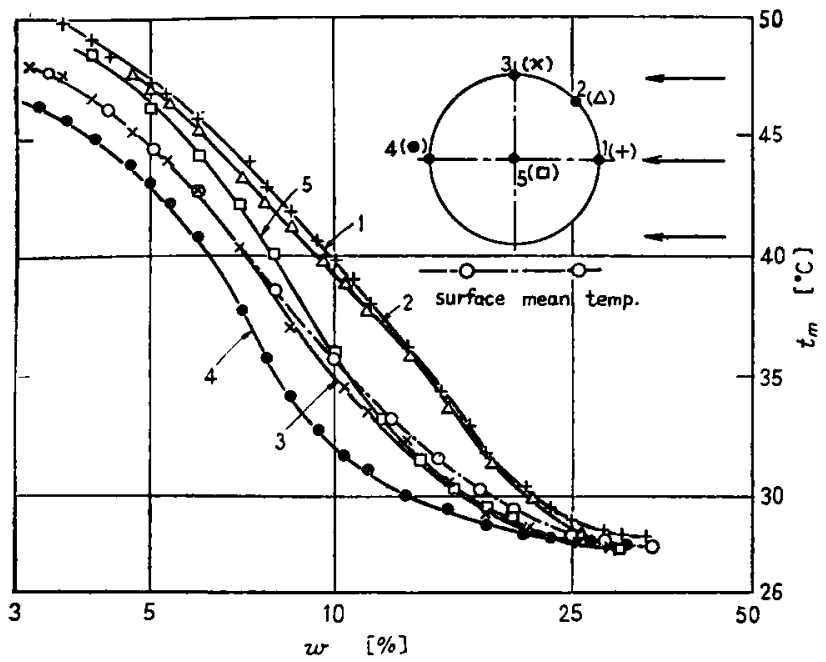

Fig. 6 Relation between the water content and the temperatures of the various points of the sphere

material. clay ; dia. $38.6 \mathrm{~mm}$; $t=55^{\circ} \mathrm{C} ; H=0.015 ; \bar{w}=1.0 \mathrm{~m} / \mathrm{sec}$

の平均表面温度を求めてこれを図に示すように点緅する と，中心材料温度とこの値と等しくならず，最大 4 〜 $\%$ の差がある。したがって直径 $4 \mathrm{~cm}$ になると材料内部温 度は均一とはいい難い。

材料表面温度が均一な場合，それと中心温度の差は， 表面の温度上年速度，粒子经，熱拡散率などの影響を受 ける。いま乾燥の場合について考穴てみると、るっとも 苛酷な条件として, 粒径が $1 \mathrm{~mm}$ 程度で材料加熱期間の 表面温度上年速度は最高 $30 \sim 50^{\circ} \mathrm{C} / \mathrm{sec}$ までである。こ の昜合，一般の材料で表面と中心の温度差は $0.5 \sim 2^{\circ} \mathrm{C}$ までである。粒径が大きくなった場合には表面温度上年 速度がゆるやかになるので，これまた中心と表面温度の 差は大した值にならないのが一般である。

以上から减率期間に打材料内温度勾配は径数 $\mathrm{mm}$ 以下では無視してかまわず，熱の授受には式 (3)が使用 できると考兄てよい。

\section{3. 材料温度と含水高の関保}

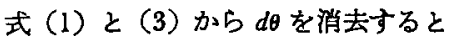

$$
\left(d t_{m} / d w\right)=\left\{r_{m}-\frac{\left(t-t_{m}\right) r_{w} F_{t}}{\left(t-t_{w}\right) F}\right\} /\left(c+c_{w} w\right)
$$

となる。 $t_{m}$ とwの関係恃式（4）をたと学ば RungKutta 法*により数值解法を行って求めればよい。ある いは式（1）と（3）からdze消去して $t_{m}$ 対 $\theta$ の閣保も同様沉求められるが，この式 には $w$ が残るので計算が複雑となる。

いま限界含水害が低く，無水材料の比熱 に対して減率期間の含水率 (最大は限界含 水率）が小さな場合を考える。

精粉体材料の畭燥にあっては，実際の装

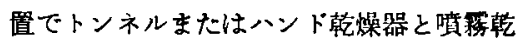
燥の場合以外ては, 粒粉体材料が分散また は擋拌されるので，その限界含水率は特殊 な場合を除いて $0.05^{62}$ 以下であり，一方 多くの材料の無水比熱は 0.3 程度であるか らこの考え方にあてはまる場合が多い。す なわら $\left(c+c_{w} w\right) \fallingdotseq c$ と近似できる。

また $r_{w}$ は $t_{w}$ に括ける蒝発潜熱であり， $i_{w}=595-0.55$ tw である。 に $t_{w}$ をいれた值であり，常用される䉥围 では $r_{\mathbf{z}} \fallingdotseq r_{w}$ と执いても大した誤差にはな らない。

この近似をいれると式（4）は

$$
\left(d t_{m} / d w\right)=\left(d t_{m} / d F\right)=\left\{r_{w}-\frac{\left(t-t_{m}\right) r_{w} F_{c}}{\left(t-t_{w}\right) F}\right\} / c
$$

となる。この微分方程式をといで*，F=F，で $t_{m}=t_{*}$ の初期条件をいれると

$$
\begin{aligned}
\left(t-t_{w}\right)= & \left(t-t_{w}\right)\left\{\frac{r_{w} F}{F_{c} r_{w}-c\left(t-t_{w}\right)}\right. \\
& \left.-\frac{c\left(t-t_{w}\right)}{F_{0} r_{w}-c\left(t-t_{w}\right)}\left(\frac{F}{F_{c}}\right)^{\frac{F_{c} r_{w}}{c\left(t-t_{w}\right)}}\right\}
\end{aligned}
$$

がえられる。これが $F$ と $t_{m}$ の関係を示す式で，接する 空気条件が与えられるとただちに計算される。

つきに限界含水率が高く，材料内水分の顕熱を考感に いれる場合について考皃る。この場合は式 (5)の右辺の 分母かi $\left(c+c_{w} w\right)$ となる。 $r_{m} \fallingdotseq r_{w}$ の近似をいれる。こ の易合は

$$
\begin{aligned}
\left(d t_{m} / d w\right) & =\left(d t_{m} / d F\right) \\
& =\left\{r_{w}-\frac{\left(t-t_{m}\right) r_{w} F}{\left(t-t_{w}\right) F_{0}}\right\} /\left\{c+c_{w}\left(w_{\bullet}+F\right)\right\}
\end{aligned}
$$

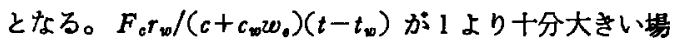
合には式 (7) の近似解を求めて, 式 (6) と類似の形と

$$
\begin{aligned}
& \text { そおけば式 (5) は } \\
& d y / d x+k_{1} y / k_{3} x=-\left(k_{2} x+k_{0}\right) / k_{3} x \\
& \text { この解俚 }
\end{aligned}
$$

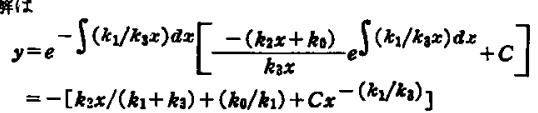

となるので佰敕をすとに民して，初期年件をいれると式（6）をえる。 


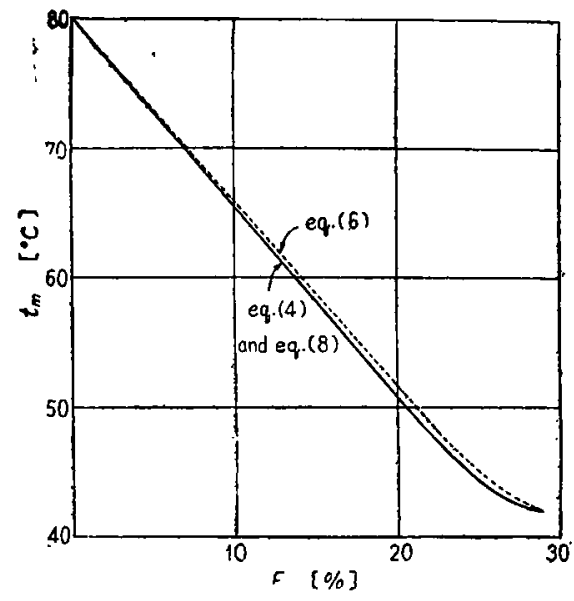

Fig. 7 Relation between water content and material temperature on the decreasing drying rate period

$\left(t=80^{\circ} \mathrm{C}, t_{w}=42^{\circ} \mathrm{C}, w_{\mathrm{c}}=0.29, w_{\star}=0, c=0.3\right)$

すると，式（8）をえる。

$$
\left(t-t_{m}\right)=\left(t-t_{w}\right)
$$

$\times\left[\frac{r_{w} F}{r_{w} F_{0}-\left(c+c_{w} w\right)\left(t-t_{w}\right)}-\frac{\left(c+c_{w} w_{c}\right)\left(t-t_{w}\right)}{r_{w} F_{c}-\left(c+c_{w} w_{c}\right)\left(t-t_{w}\right)}\right.$

$\left.\times\left\{\frac{F\left(c+c_{w} w_{c}\right)}{F_{c}\left(c+c_{w} w\right)}\right\}^{\frac{P_{c} r_{w}}{\left(c+c_{w b} w_{e}\right)\left(t-t_{w}\right)}}\right]$

この式は以下の例題に示すように上述の範囲ては，逐 次解とよい一致を示すので使用することができる。 $\left.\left\{F_{0} \dot{r}_{w} / c+c_{w} w_{c}\right)\left(t-t_{w}\right)\right\} \gg 1$ というのは, $F_{c} \cdot c_{w}[\mathrm{kcal} /$ ${ }^{\circ} \mathbf{C} \cdot \mathbf{k g}$ 無水材料] が無水材料比熱 $c$ にくらべて，それ に近いか，まかはそれより大きく，しかる $\left(t-t_{w}\right)$ が比 較的小さい場合である。すなわち限界含水率が高くて $\left(F_{\mathrm{c}}=0.2\right.$ 以上), 比校的低温 $\left(t=150^{\circ} \mathrm{C}\right.$ 以下) の熱風 を用いた場合に成立する

乾燥条件の5ら風速は材料温度に関係しない。

いま乾燥条件として $t=80, t_{w}=42$ の熱風に接触する 粒粉体材料の減率期閒に拈ける温度上晨を式 (4)の数值 解および式 (6)，式(8)について計算した結果を Fig.7 に示した。たたし $c=0.30, w_{c}=0.29, w_{0}=0$ の場合で ある。 $w_{c}$ が高く, $\left(t-t_{w}\right)$ が小さいので $F_{c} r_{w} /\left(c+c_{w} w_{0}\right)$ $\times\left(t-t_{x 0}\right)=15$ となり, 式 (8) は数值解とほとんど一致 している。

つきに $t=400, t_{w 0}=60$ の乾操条件で $c=0.30, \quad w_{c}=$ 0.05, $w_{\text {。 }}=0$ の場合に同様の計算を行い結果を Fig. 8 に示した。この場合は $F_{0} r_{w} /\left(c+w_{0}\right)\left(t-t_{w}\right)=0.337$ と なり，式（6）がよい一致を示している。

このよ5に定常乾燥条件における減率期間の温度は式 （4）の数值解によらなくてる式（6）または式（8）で十

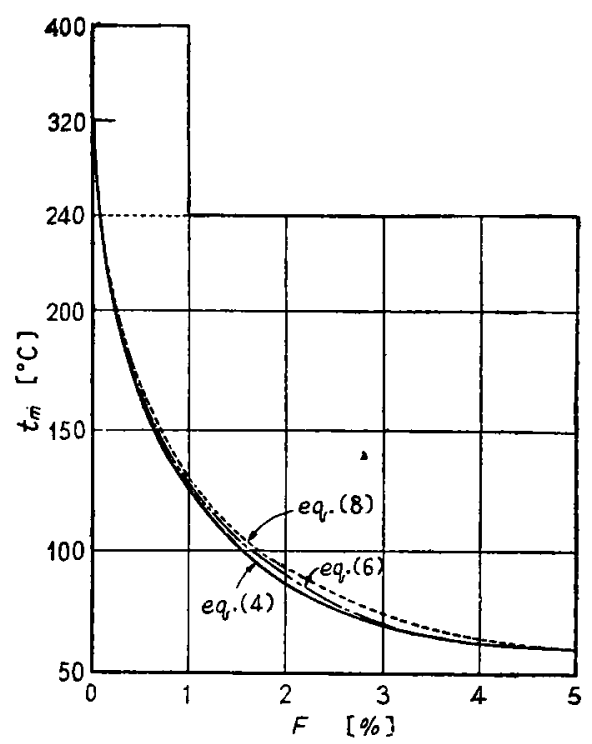

Fig. 8 Relation between water content and material temperature on the decreasing drying rate period

$\left(t=400^{\circ} \mathrm{C}, t_{w}=60^{\circ} \mathrm{C}, w_{c}=0.05, w_{t}=0, c=0.3\right)$

分な精度の計算結果がえられる。

\section{III. 不定常乾燥条件下の乾燥}

材料および熱風が相互に並流または向流に移動する昜 合には，材料に接する乾燥条件は次第に变化するので材 料は不定常乾燥を受けることとなる。熱風連秸乾燥器内 の状態がこれである。断熱加熱の場合には

$$
h A\left(t-t_{m}\right) d \theta= \pm G C_{B} d t \quad \text { 十向流, 一亚流 (9) }
$$
が成立する。さらに式（1）拈よび式（3）で $W_{0}$ をW， $A_{0}$ を $A$ に怙きかえた式が任意の断面で成立するから

$$
\begin{aligned}
W(-d w) / A d \theta & =k\left(H_{w}-H\right) F / F_{c} \\
& =h\left(t-t_{w}\right) F / r_{w} F_{c}=K F \\
h A\left(t-t_{m}\right) d \theta= & W r_{m}(-d w)+W\left(c+c_{w} v\right) d t_{m}
\end{aligned}
$$

となる。

式（9）と式（11）より，装置内任意の 2 断面 $A, B$ K 标いて

$$
[G i]_{A}^{B}=\left[W\left(c+C_{w} w\right) t_{m}\right]_{A}^{B}
$$

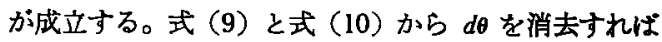

$$
(d t / d w)= \pm \frac{W r_{w}\left(t-t_{m}\right) F_{e}}{G C_{H}\left(t-t_{w}\right) F} \quad+\text { 並流, 一向流 (13) }
$$

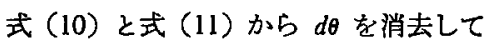

$$
\left(d t_{m} / d w\right)=\left\{r_{m}-\left(\frac{t-t_{m}}{t-t_{w}}\right) \frac{r_{w} F_{c}}{F}\right\} /\left(c+c_{w} w\right)
$$

式 (13)，(14）の聯立微分方程式をとけば， $t, t_{m}, F$ の 関係が求まるが，解析的な解がえられないので数值解に 
Table 1 Calculated results of examples obtained by means of Eqs. (13) and (14)

2) Parallel current adiabatic dryer $(G / W)=3, c=0.3, w_{0}=0$ drying conditions at the critical water content

$t_{c}=300, H_{0}=0.03, w_{c}=0.20$ $t_{\mathrm{m}}=t_{w_{0}}=60.0$

\begin{tabular}{ccc}
$F$ & $t$ & $t_{n}$ \\
\hline 0.20 & 300 & $-\ldots 0.0$ \\
0.19 & 290.8 & 60.5 \\
0.18 & 281.5 & 61.6 \\
0.17 & 271.6 & 63.3 \\
0.16 & 261.4 & 65.5 \\
0.15 & 250.8 & 69.5 \\
0.14 & 240.5 & 74.0 \\
0.13 & 230.6 & 79.4 \\
0.12 & 218.8 & 85.4 \\
0.11 & 207.4 & 92.1 \\
0.10 & 196.5 & 99.8 \\
0.69 & 186.0 & 107.2 \\
0.08 & 175.3 & 114.5 \\
0.07 & 165.0 & 120.3 \\
0.06 & 156.4 & 124.3 \\
0.05 & 148.5 & 126.4 \\
0.04 & 142.6 & 127.5
\end{tabular}

b) Counter current adiabatic dryer $(G / W)=5, c=0.3, w_{\bullet}=0$ drying conditions at the critical water content $t_{\mathrm{e}}=200, H_{c}=0.05, w_{\varepsilon}=0.20$ $t_{m_{\mathrm{c}}}=t_{w_{\mathrm{c}}}=56.0$

\begin{tabular}{|c|c|c|}
\hline$F$ & $t$ & $t_{m}$ \\
\hline $\begin{array}{l}0.20 \\
0.19 \\
0.18 \\
0.17 \\
0.16\end{array}$ & $\begin{array}{l}200 \\
205 \\
210 \\
215.5 \\
221.5\end{array}$ & $\begin{array}{l}56.0 \\
56.5 \\
57.7 \\
59.3 \\
61.5\end{array}$ \\
\hline $\begin{array}{l}0.15 \\
0.14 \\
0.13 \\
0.12 \\
0.11\end{array}$ & $\begin{array}{l}228 \\
234 \\
240.6 \\
248 \\
255\end{array}$ & $\begin{array}{l}65.0 \\
69.0 \\
74.5 \\
81.3 \\
89.5\end{array}$ \\
\hline $\begin{array}{l}0.10 \\
0.09 \\
0.08 \\
0.07 \\
0.06\end{array}$ & $\begin{array}{l}263.5 \\
272 \\
281 \\
290.5 \\
300.5\end{array}$ & $\begin{array}{l}98.5 \\
110 \\
125 \\
141 \\
160.5\end{array}$ \\
\hline $\begin{array}{l}0.05 \\
0.04 \\
0.03 \\
0.02\end{array}$ & $\begin{array}{l}311.5 \\
323 \\
335 \\
348\end{array}$ & $\begin{array}{l}182 \\
208 \\
238 \\
273\end{array}$ \\
\hline
\end{tabular}

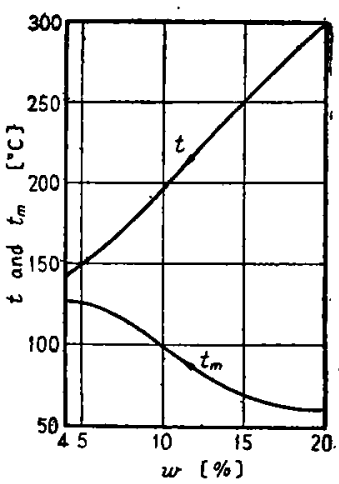

Fig. 9 Relations a mong $F$ vs. $t$ and $t_{m}$ (Table 1 a) Parallel current dryer)

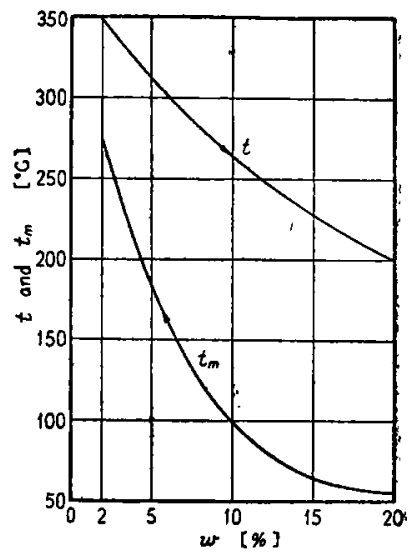

Fig. 10 Relations among $F$ vs. $t$ and $t_{m}$

(Table 1 b) Counter current dryer)

並流ならびに向流の場合について式（13），(14）を用 いてといた例を Table 1 および Fig. 9 と Fig. 10 に あげた。

なお Runge-Kutta 法による昜合の $\Delta F$ の区間のとり 方についての誤差は $F_{0}$ が $0.2 \sim 0.3$ 程度では - $(0.03$ $\sim 0.05), F_{0}$ が 0.05 以下ならば $-(0.01 \sim 0.005)$ にと って十分の精度がある。また式 (9)〜(11) からdwを 消去すると

$$
\begin{aligned}
& (d t / d \theta)= \pm h A\left(t-t_{m}\right) / G C_{B}+\text { 並流, 一向流 } \\
& \left(d t_{m} / d \theta\right) \\
& \quad=\left\{h A\left(t-t_{m}\right)-r_{m} h A\left(t-t_{w}\right) F / F_{\mathrm{e}} r_{w}\right\} / W\left(c+c_{w} w\right)
\end{aligned}
$$

となり, $t, t_{m}$ と $\theta$ の関係を同様に数值解から求めるこ ともできる。

また並流括よび向流乾燥器において，乾燥器出口の希 望含水率に対応する村料温度の近似計算としては, 希望 含水率の材料が材料出口の空気条件で定常乾燥を受けて

希望含水率になっ たときに示す材料 温度としてかまわ ないすすなわち布 望含水率と材料出 口空気条件を式 （6）または式 (8) に代入して求めた $t_{m}$ 之近似できる。 これは現在までの 乾燥速度の近似計算法と全く同一の仮定にたつむのであ， りまた計算例によってもこの近似と式 (13)，(14)より の精密解の差は $1 \sim 3{ }^{\circ} \mathrm{C}$ 以内にとどまることがわかる。

これらの計算例および乾燥器の設計に対する適用に関

しては交献 8）を参照せられたい。

\section{Nomenclature}

$A$ : drying area of $W$ $\left[\mathrm{m}^{2} / \mathrm{hr}\right]$

$A_{0}$ : drying area of $W_{0}$ $\left[\mathrm{m}^{2}\right]$

$c$ : specific heat of bone dry material

$\left[\mathrm{kcal} / \mathrm{kg} \cdot{ }^{\circ} \mathrm{C}\right]$

$c_{w}$ : specific heat of water $=1 \quad\left[\mathrm{kcal} / \mathrm{kg} \cdot{ }^{\circ} \mathrm{C}\right]$

$C_{H}$ : humid heat of air

$\left[\mathrm{kcal} / \mathrm{kg} \cdot{ }^{\circ} \mathrm{C}\right]$

$F$ : free water content $F=\left(w-w_{0}\right) \quad[-]$

$F_{c}$ : value at critical water content

$G$ : gas rate (dry)

$[\mathrm{kg} / \mathrm{hr}]$ 
$h$ : heat transfer coefficient $\left[\mathrm{kcal} / \mathrm{hr} \cdot \mathrm{m}^{2} \cdot{ }^{\circ} \mathrm{C}\right]$

$H$ : humidity

[kg-steam/kg-dry air]

$H_{c}$ : value at critical water content

$H_{w}$ : saturated humidity at temp. $t_{w}{ }^{\circ} \mathrm{C}$

$i$ : enthalpy of air

[kcal/kg-dry air]

$k$ : mass transfer coefficient

[kg-dry air $\left./ \mathrm{hr} \cdot \mathrm{m}^{2}\right]$

$K:=h\left(t-t_{w}\right) / r_{w} F_{\text {。 }}$

$L$ : dryer length

[m]

$r_{w}$ : heat of vaporization at $t_{w}{ }^{\circ} \mathrm{C}$

$r_{w}=595-0.55 t_{w}$

[kcal/kg-steam]

$r_{m}$ : heat of vaporization at $t_{m}{ }^{\circ} \mathrm{C}$

$t:$ temp. of gas

$t_{e}:$ temp. of gas at crytical water content $\left[{ }^{\circ} \mathrm{C}\right]$

$t_{w}$ : wet bulb temp.

$\left[{ }^{\circ} \mathbf{C}\right.$ ]

$t_{m}:$ temp. of material

$t_{w_{c}} \cdot t_{w}$ at critical water content

$t_{m_{m}}, t_{m_{s}}, t_{m_{c}}: t_{m}$ of mean, on surface and at critical water content

$\left[{ }^{\circ} \mathbf{C}\right]$ $\bar{u}:$ linear velocity of air $[\mathrm{m} / \mathrm{sec}]$

$W$ : feed rate of bone dry material $[\mathrm{kg} / \mathrm{hr}]$

$W_{0}:$ bone dry weight [kg]

$w$ : water content [-]

$w_{s}$ : critical water content [-]

$w_{0}$ : equilibrium water content [-]

$\theta$ : drying time [hr]

$\theta_{d}$ : drying time of decreasing drying rate period [min]

$\rho_{m}$ : density of material $\left[\mathrm{kg} / \mathrm{m}^{3}\right]$

\section{Literatures cited}

1) Bloomfield G. F. . J. S. C. I., 68, 59 (1949)

2) Kamei S. et al:Chem. Eng. (Japan), 13, 103 (1949)

3) Ibid. $\quad$ Ibid. 14,73 (1950)

4) Ibid. $\quad$ Ibid. 16, 294 (1952)

5) Ibid. $\quad$ Ibid. 20, 55 (1956)

6) "Kagaku-Kögaku Benran," p. 544 (1958)

7) Toei R. et al : Wakayama Meeting. Soc. of Chem. Engrs. (Japan), Nov. (1958)

8) Toei R. : "Kagaku Kikai Gijutsu," No. 11, 143 (1959)

\title{
Drying Process Analysis of the Decreasing Drying Rate Period of Granular and Powder Material
}

\author{
R. Toei, * S. Hayashi, ** T. Naito,*** \\ M. Okazaki, **** and M. Agata*****
}

I. On the stational drying conditions :

The drying rate curves for various materials and methods from which Eq. 1 is derived are shown in Figs. 1-4. It is clear from these that the decreasing drying rate of granular material is proportional to the water content of the material.

The heat transfer between air and material is shown by Eq. (2). When the temp. gradient of the material is negligibly small, Eq. (3) is obtained. As shown in Figs. 5 and 6, the temp. gradient can be neglected for the granular material whose diameter is below $2-3 \mathrm{~mm}$.

Eq. (4) derived from Eqs. (1) and (3) may be solved numerially, e. g., by Runge-Kutta's method.

When the sensible heat of water $\left(w_{0} \cdot c_{w}\right)$ contained in the material is small as compared with the specific heat of the dried material and $r_{m} \fallingdotseq r_{w}$, Eq. (5) can be solved analytically:

$$
\left(t-t_{m}\right)=\left(t-t_{w}\right)\left\{\frac{r_{w} F}{F_{0} r_{w}-c\left(t-t_{w}\right)}-\frac{c\left(t-t_{w 0}\right)}{F_{c} r_{w}-c\left(t-t_{w p}\right)}\left(\frac{F}{F_{c}}\right)^{\frac{F_{c} r_{w}}{c\left(t-t_{w}\right)}}\right\}
$$

In case $\left(w_{v} \cdot c_{w}\right)$ has a value comparable to the specific heat of the material, $F_{c} r_{w} /\left(c+c_{w} w_{0}\right)\left(t-t_{w}\right) \gg I$ and $r_{m} \fallingdotseq r_{w}$, the following approximate equation, Eq. (8), can be obtained.

$$
\left(t-t_{m}\right)=\left(t-t_{w}\right)\left[\frac{r_{w} F}{r_{w} F_{c}-\left(c+c_{w} w\right)\left(t-t_{w}\right)}-\frac{\left(c+c_{w} w_{c}\right)\left(t-t_{w}\right)}{r_{w} F_{0}-\left(c+c_{w} w_{0}\right)\left(t-t_{w}\right)}\left\{\frac{F\left(c+c_{w} w_{c}\right)}{F_{0}\left(c+c_{w} w\right)}\right\}^{\frac{P_{c} v_{w}}{\left(c+c_{w} w_{b}\right)\left(t-t_{w}\right)}}\right]
$$

* Kyoto Univ., Faculty of Eng. * Idemitsu-Kosan Co. *** Teikoku Rayon Co. 
Eqs. (6) and (8) give the relation between $t_{-}$and $w$.

II. On the unsteady drying conditions :

The unsteady drying which takes place in a continuous (parallel or counter current) dryer, such as a rotary, pneumatic conveying, spary or fluidized-bed dryer, can be presented by Eqs. (9)-(12). From these are derived Eqs. (13) and (14), whose solutions show the relations among $t, t_{\mathrm{m}}$ and $w$ in the dryer.

These equations could be solved numerially. The calculated examples are shown in Table 1 and Figs. 9 and 10.

The drying rate and the drying time in the continuous adiabatic dryer which can be easily calculated by using these relations may help to decide the dryer volume.

The application of this calculation method to the dryer design would be expatiated upon in our report $^{8)}$.

\section{粘 度計のさまざま}

使用目的括よび筙囲によって温度計が分類されている ので（たとえば”化学便覽”， p. 1057 を参照），不明な 点る多いが夜体用粘度計を表のことく分類してみた。こ の他にレッドゥッド粘度計を改良したタール粘度計など 多くあるが，代婊的粘度計と考えられるるののみを示し た。

毛細管式と短管式なとでは粘度として動粘度 $\mu / \rho(\mu$ は粘度， $\rho$ は密度）を使用し，振動法では理論的基礎よ ク $\mu \rho$ で表示している。一方オストワールド粘度計の改 良型のキャノンフェンスケ粘度計では 0.4 16,000c.s., ウヘローデ粘度計では 2.0〜10,000 c.s. の筑团で測定で きる。それで使用籍囲の航一のために， $\rho=1 \mathrm{gr} / \mathrm{cm}^{3}$ と して，毛細管式では 10-1〜104 c.p. として表に示した。 回転粘度計は一般に高粘度用であり，円筒の代りに円錐 や平板を使用したのるある。

この表中で筆者が面白 いと思ったるのを 2〜3 述へてみる。細管式連続 粘度計は第 1 図のこととき むのである。管内の流れ が屡流であればポアズイ ユの式より王力降下は平 均流速 と粘度に比例する から，ハイブライン粘度 計では压力降下と平均流 速を测定して粘度を䚺算 している。平均流速を一

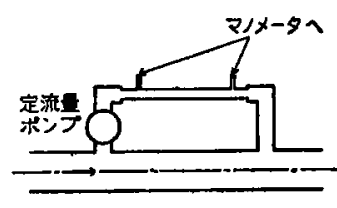

第1図

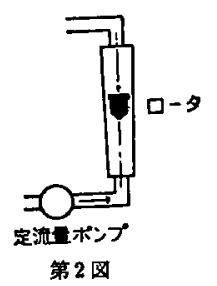

定にすれば纴力降下の测定のみで粘度を知ることができ ろ。このことを応用したのが細管式連続粘度計であり， 主管の横の細管に定流量ボンブをつけて流速を一定にし ている。

浮子式粘度計はロータメータを応用したものである。 ロータメータではロータの位置が流量飞比例している が，第2図のことく定流量ボンブによって流量を一定に， したので，ロータの位置が粘度に比例することになる。 これらと同様な考え方からオリフィスも利用できるので はないかと思う。な技計装に使用されるのは細管式連続 粘度計と振動片粘度計のようである。

以上は扰もに JIS K 2272 (1954), 同 2283 (1956), 川田裕郎著“粘度”こロナ社 (1958) 和よびカタログを 参考にした。

(平 井)

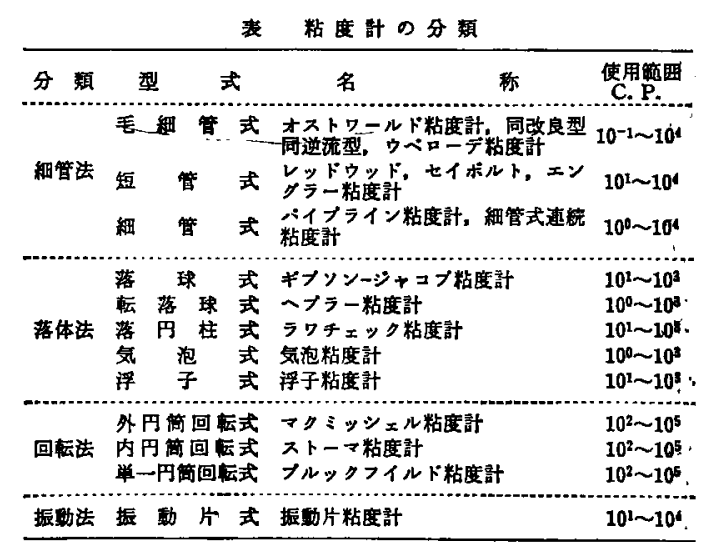

